\title{
Molecular genetic analysis of strawberry genotypes for the FaOMT fruit aroma gene
}

\author{
Irina Luk'yanchuk* \\ Federal State Scientific Institution "I.V. Michurin Federal Science Center", 30. Michurin st., \\ Michurinsk, Tambov region, Russia, 393774
}

\begin{abstract}
The results of the analysis of allelic polymorphism of strawberry varieties and forms for the FAOMT fruit aroma gene were shown. The non-functional allele FaOMT- in the homozygous state was detected in strawberry variety Quicky. Heterozygous genotype $(\mathrm{FaOMT}+\mathrm{FaOMT}$-) was identified in the strawberry varieties Feyerverk, Ostara, Polka and Symphony, and selected forms 26-5 and 928-12. The functional allele $F a O M T$ gene $(F a O M T+)$ in the homozygous state $(\mathrm{FaOMT}+\mathrm{FaOMT}+$ genotype) was detected in strawberry varieties Borovitskaya, Kubata, Troitskaya, Tsaritsa, Yarkaya, Korona and Vima Kimberly, and selected forms 932-29 and 298-19-9-43, which allows us to be used as valuable initial forms in breeding for fruit aroma.
\end{abstract}

\section{Introduction}

Strawberry is one of the most widespread berry crops in the world. Its popularity is due to such traits as early harvest maturity, dessert taste, aroma and rich biochemical composition of the fruit $[1,2]$. It should be noted that the strawberry breeding is mainly aimed at improving the commercial qualities of fruits, productivity and plant resistance to unfavorable biotic factors, while the improvement of such consumer qualities as the biochemical composition and aroma of fruits was carried out insufficiently, which led to a decrease in these traits in many widely cultivated strawberry varieties [3, 4].

The pleasant aroma of strawberry fruits is due to the content of a large amount of volatile organic compounds. In strawberry fruits over 360 volatile compounds reported [57]. The most important components of the aromatic profile of strawberry fruits are about 20 volatile compounds. These include 2,5-dimethyl-4-hydroxy-3 $(2 \mathrm{H})$-furanone (furaneol) and 4-methoxy-2,5-dimethyl-3-furanone (mesifurane). Furaneol and mesifurane add sweet and caramel notes to the strawberry aroma $[8,9]$.

The furanones content in strawberry fruits are dependent on the genotype, the degree of fruit maturity and environmental conditions during their growth and development $[3,10$, 11]. Moreover, unlike most quantitative traits of strawberry, the formation of which is due to polygenic effects, the concentration of 4-methoxy-2,5-dimethyl-3-furanone in fruits is controlled by the dominant FaOMT gene. The FaOMT gene has two allelic states. Allele

* Corresponding author: irina.1k2011@yandex.ru 
$\mathrm{FaOMT}+$ determines a high level of accumulation of mesifurane in strawberry fruits. Allele $\mathrm{FaOMT}$ - is inactive (non-functional). The active allele $(\mathrm{FaOMT}+$ ) differs from the inactive allele $(F a O M T$-) by the presence in the promoter of several SNPs (Indel) containing potential regulatory elements - the E-box/RRE motif, the MYBL motif, and the ABRE/ACGT motif. [12]. Monogenic control of the mesifurane content in strawberry fruits is also confirmed by the RNA interference, which showed an almost complete absence of mesifurane in strawberry fruits during repression of the FaOMT transcripts [13]. Identification of the main determinants of this trait allows screening of promising forms based on molecular markers $[12,14]$.

The purpose of study was to study the allelic diversity of the FaOMT fruit aroma gene in strawberry varieties in order to identify promising genotypes for involvement in the strawberry breeding to improve the aroma of fruits.

\section{Methods}

The studies were carried out in 2019-2020. Biological material was represented by strawberry varieties and selected forms from genetic collection of the FSSI "I.V. Michurin Federal Science Center".

Total genomic DNA of strawberry genotypes was extracted using the Diversity Arrays Technology P/L (DArT) protocol with modifications $[15,16]$.

The alleles of FaOMT gene were identified with the primers FaOMT-SI/NO-F (5'CGATCATTTCGAAAAGGACTA-3') and FaOMT-SI/NO-R (5'AAGCAGGGTTAGTTGTGGAGA-3'). The FaOMT+ allele on the electrophoregram corresponds to a $248 \mathrm{bp}$ fragment, the $\mathrm{FaOMT}$ - allele corresponds to a $214 \mathrm{bp}$ fragment [10].

Reaction mix in final volume $15 \mu$ l containing $1.5 \mu$ l Taq-buffer, $0.2 \mathrm{mM}$ of each deoxyribonucleotide triphosphate, $2.5 \mathrm{mM}$ magnesium chloride, $0.2 \mathrm{U}$ Taq DNA polymerase, $0.2 \mu \mathrm{M}$ of each primer and $20 \mathrm{ng}$ of genomic DNA.

The polymerase chain reaction was performed in T100 Thermal Cycler (BioRad). PCR conditions were as follows: 3 min denaturation at $95^{\circ} \mathrm{C}$ followed by 10 cycles of $30 \mathrm{~s}$ at $95^{\circ} \mathrm{C}, 30 \mathrm{~s}$ at $60^{\circ} \mathrm{C}\left(-0.5^{\circ} \mathrm{C} /\right.$ cycle $)$, and $45 \mathrm{~s}$ at $72{ }^{\circ} \mathrm{C}$, then 25 cycles of $30 \mathrm{~s}$ at $95^{\circ} \mathrm{C}, 30 \mathrm{~s}$ at $55^{\circ} \mathrm{C}$, and $45 \mathrm{~s}$ at $72^{\circ} \mathrm{C}$, followed by a final extension step of $5 \mathrm{~min}$ at $72^{\circ} \mathrm{C}$.

Amplification products were separated by electrophoretic method in agarose gel (agarose concentration $-2 \%$, running buffer $-1 \mathrm{x}$ TBE). Amplicon sizes estimated were performed using the Gene Ruler 100 bp DNA Ladder (Thermo Fisher Scientific).

\section{Results}

According to the research the functional allele $\mathrm{FaOMT}+$ was detected in 15 forms $(93.7 \%)$ out of 16 analyzed genotypes. The FaOMT- allele was identified in $43.7 \%$ analyzed forms. The FaOMT+FaOMT- genotype was identified in $37.5 \%$ forms. The $\mathrm{FaOMT}+\mathrm{FaOMT}+$ genotype was detected in $56.2 \%$ forms. The homozygous state of nonfunctional allele was identified in foreign strawberry variety Quicky (the example of electrophoresis profile of markers FaOMT-SI/NO is shown in Fig. 1, the results are shown in Tab. 1.). 


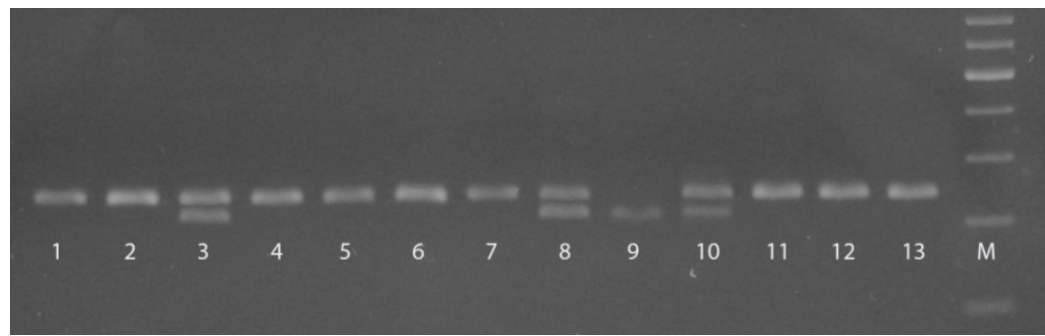

Fig. 1. Electrophoresis profile of markers FaOMT-SI/NO at strawberry genotypes 1 - Borovitskaya, 2 - 298-19-9-43, 3 - 26-5, 4 - Korona, 5 - Vima Kimberly, 6 - Yarkaya, 7 - Troitskaya, 8 - Ostara, 9 - Quicky, 10 - Polka, 11 - 932-29, 12 - Kubata, 13 - Tsaritsa, $\mathrm{M}$ - Molecular weight marker

Table 1. Allelic polymorphism of FaOMT gene in strawberry varieties and forms ( 1 - allele is presence, 0 - allele is absence)

\begin{tabular}{|c|c|c|c|}
\hline \multirow{2}{*}{ № } & \multirow{2}{*}{ Genotype } & \multicolumn{2}{|c|}{ FaOMT } \\
\hline & & $217 \mathrm{bp}$ & $248 \mathrm{bp}$ \\
\hline 1 & Borovitskaya (Nadezhda $\times$ Red Gauntlet) & 0 & 1 \\
\hline 2 & Kubata (Kubenskaya $\times$ Holiday) & 0 & 1 \\
\hline 3 & Troitskaya $(F . \times$ ananassa Duch. $\times F$. moschata Duch. $)$ & 0 & 1 \\
\hline 4 & Feyerverk (Zenga Zengana $\times$ Redcoat) & 1 & 1 \\
\hline 5 & Tsaritsa (Venta $\times$ Red Gauntlet) & 0 & 1 \\
\hline 6 & Yarkaya (Zenga Zengana $\times$ Redcoat) & 0 & 1 \\
\hline 7 & Korona (Tamella $\times$ Induka) & 0 & 1 \\
\hline 8 & Ostara (Red Gauntlet $\times$ Masherahs Daurernte) & 1 & 1 \\
\hline 9 & Polka $($ Unduka $\times$ Sivetta $)$ & 1 & 1 \\
\hline 10 & Quicky (CIVN251) & 1 & 0 \\
\hline 11 & Symphony (Rhapsody $\times$ Holiday) & 1 & 1 \\
\hline 12 & Vima Kimberly (Gorella $\times$ Chandler) & 0 & 1 \\
\hline 13 & $\begin{array}{l}\text { 298-19-9-43 [(F. orientalis Los. } \times F . \text { moschata } \text { Duch. }) \times F \\
\text { ananassa } \text { Duch.] }\end{array}$ & 0 & 1 \\
\hline 14 & $\begin{array}{l}26-5(F . \text { ananassa } \text { Duch. } \times[(F . \text { orientalis Los. } \times F . \text { moschata } \\
\text { Duch. }) \times F \text {. ananassa } \text { Duch. }])\end{array}$ & 1 & 1 \\
\hline 15 & $\begin{array}{l}\text { 928-12 [(F. orientalis Los. } \times F . \text { moschata } \text { Duch. }) \times F \\
\text { ananassa } \text { Duch. }]\end{array}$ & 1 & 1 \\
\hline 16 & $\begin{array}{l}\text { 932-29 (F. virginiana Duch. ssp. platypetala } \times F \text {. ananassa } \\
\text { Duch.) }\end{array}$ & 0 & 1 \\
\hline
\end{tabular}

In most of the analyzed strawberry varieties $(58.3 \%)$, the active allele of the $F a O M T$ gene is present in a homozygous form. It should be noted that out of six strawberry varieties of Russian breeding, the homozygous genotype for the FaOMT gene $(\mathrm{FaOMT}+\mathrm{FaOMT}+$ ) was identified in five genotypes (Borovitskaya, Kubata, Troitskaya, Tsaritsa, Yarkaya), while among 6 varieties of foreign breeding - only in two forms (Netherlands' strawberry varieties Korona and Vima Kimberly). More widespread of the heterozygous genotype of the $\mathrm{FaOMT}$ gene in foreign strawberry forms also shown in other studies $[17,18]$. The prevalence of the $F a O M T+F a O M T$ - genotype in foreign strawberry varieties can be explained by their genetic proximity due to the active use of several initial forms in hybridization, which presumably could be a donor of the inactive $\mathrm{FaOMT}$ - allele.

Among the analyzed selected forms of strawberry, homozygous state of the FaOMT+ allele was identified in hybrids 298-19-9-43 and 932-29. Selected forms 26-5 and 928-12 have the $\mathrm{FaOMT}+\mathrm{FaOMT}$ - genotype. 
Thus, as a result of the research, we studied the allelic polymorphism of the FaOMT gene, which determines the content of 4-methoxy-2,5-dimethyl-3-furanone (mesifurane) in strawberry fruits. Valuable sources of increased concentration of mesifurane in fruits are strawberry varieties Borovitskaya, Kubata, Troitskaya, Tsaritsa, Yarkaya, Korona and Vima Kimberly, and hybrid forms 932-29 and 298-19-9-43 (FaOMT+FaOMT+ genotype).

\section{References}

1. F. Giampieri, S. Tulipani, J.M. Alvarez-Suarez, J.L. Quiles, B. Mezzetti, M. Battino, Nutrition, 28(1), 9-19 (2012) https://doi.org/10.1016/j.nut.2011.08.009

2. A. Michalska, C. Carlen, J. Heritier, W. Andlauerc, J. Berry Res., 7(2), $71-84$ (2017). https://doi.org/10.3233/JBR-160146

3. D. Ulrich, K. Olbricht, J. Appl. Bot. Food Qual., 89, 223-234 (2016). https://doi.org/10.5073/JABFQ.2016.089.029

4. G. Bianchi, P. Lucchi, M.L. Maltoni, A.F. Fagherazzi, G. Baruzzi, Acta Hortic., 1156, 673678 (2017). https://doi.org/10.17660/ActaHortic.2017.1156.98

5. G. Cumplido-Laso, L. Medina-Puche, E. Moyano, T. Hoffmann, Q. Sinz, L. Ring, C. StudartWittkowski, J. L. Caballero, W. Schwab, J. Muñoz-Blanco, R. Blanco-Portales, J. Exp. Bot., 63(11), 4275-4290 (2012). https://doi.org/10.1093/jxb/ers120

6. M. L. Schwieterman, T. A. Colquhoun, E. A. Jaworski, L. M. Bartoshuk, J. L. Gilbert, D. M. Tieman, A. Z. Odabasi, H. R. Moskowitz, K. M. Folta, H. J. Klee, C. A. Sims, V. M. Whitaker, D. G. Clark, PloS One, 9(2), e88446 (2014). https://doi.org/10.1371/journal.pone.0088446

7. C. Song, X. Hong, S. Zhao, J. Liu, K. Schulenburg, F.C. Huang, K. Franz-Oberdorf, W. Schwab, Plant Physiol., 171(1), 139-151 (2016). https://doi.org/10.1104/pp.16.00226

8. A. H. Chambers, J. Pillet, A. Plotto, J. Bai, V. M. Whitaker, K. M. Folta, BMC genomics, 15(1), 217 (2014). https://doi.org/10.1186/1471-2164-15-217

9. M. Urrutia, J. L. Rambla, K. G. Alexiou, A. Granell, A. Monfort, Plant Physiol. Bioch., 121, 99-117 (2017). https://doi.org/10.1016/j.plaphy.2017.10.015

10. J. W. Yan, Z. J. Ban, H. Y. Lu, D. Li, E. Poverenov, Z. S. Luo, L. Li, J. Sci. Food Agr., 98(12), 4395-4402 (2018). https://doi.org/10.1002/jsfa.9039

11. A. Yamada, K. I. Ishiuchi, T. Makino, H. Mizukami, K. Terasaka, Biosci. Biotech. Biochem., 83(1), 106-113 (2019). https://doi.org/10.1080/09168451.2018.1524706

12. Y. Zorrilla-Fontanesi, J. L. Rambla, A. Cabeza, J. J. Medina, J. F. Sánchez-Sevilla, V. Valpuesta, M. A. Botella, A. Granell, I. Amaya, Plant physiol., 159(2), 851-870 (2012). https://doi.org/10.1104/pp.111.188318

13. K. Härtl, G. Kalinowski, T. Hoffmann, A. Preuss, W. Schwab, Plant Biotechnol. J., 15(5), 658-668 (2017). https://doi.org/10.1111/pbi.12664

14. M. C. Gor, C. Candappa, T. de Silva, N. Mantri, E. Pang, Scientific reports 7(1), 1-13 (2017). http://doi.org/10.1038/s41598-017-17448-1

15. I. V. Luk'yanchuk, A. S. Lyzhin, I. I. Kozlova, Vavilov Journal of Genetics and Breeding 22(7), 795-799 (2018). https://doi.org/10.18699/VJ18.423

16. A. S. Lyzhin, I. V. Lukyanchuk, E. V. Zhbanova, Proceedings on Applied Botany, Genetics and Breeding 180(1), 73-77 (2019). https://doi.org/10.30901/2227-8834-2019-1-73-77

17. A. S. Lyzhin, I. V. Luk'yanchuk, E. V. Zhbanova, Vavilov Journal of Genetics and Breeding 24(1), 5-11 (2020). https://doi.org/10.18699/VJ20.588

18. E. Cruz-Rus, R. Sesmero, J. A. Ángel-Pérez, J. F. Sánchez-Sevilla, D. Ulrich, I. Amaya, Mol. Breed., 37(10), 131 (2017). https://doi.org/10.1007/s11032-017-0732-7 